DOI: https://doi.org/10.34069/AI/2021.48.12.13

How to Cite:

Gorbenko, V., Busurina, E., Kuraleva, I., Burmistrova, T., \& Kolbasenkova, A. (2021). Assessment and comparison of adaptation levels of foreign students at pre-university training programs. Amazonia Investiga, 10(48), 117-128. https://doi.org/10.34069/AI/2021.48.12.13

\title{
Assessment and comparison of adaptation levels of foreign students at pre-university training programs
}

\section{Оценка и сравнение уровней адаптации иностранных студентов на программах предвузовской подготовки}

Ekaterina Busurina ${ }^{45}$

https://orcid.org/0000-0002-3500-8710

https://www.elibrary.ru/author_profile.asp?authorid=283005 https://www.scopus.com/authid/detail.uri?authorId=57217988920 https://publons.com/researcher/3477793/ekaterina-vadimovna-busurina/

Irena Kuraleva ${ }^{46}$

https://orcid.org/0000-0001-7027-3707

https://www.elibrary.ru/author_profile.asp?authorid=1051329

Tatiana Burmistrova ${ }^{47}$

https://orcid.org/0000-0002-8357-1823

https://www.elibrary.ru/author_profile.asp?authorid=282634

Aleksandra Kolbasenkova ${ }^{48}$

https://orcid.org/0000-0001-5699-0793

https://www.elibrary.ru/author_profile.asp?authorid=1107608

\begin{abstract}
Successful adaptation of foreign students to higher education system and life in Russia is an actual objective of all pre-university training programs. The purpose of this study is to identify the level of academic, social and psychological, and personal adaptation of foreign students of the pre-master's training program in comparison with the adaptation level of future foreign bachelors. In empirical research the authors analyzed responses of 92 foreign students of the pre-university training programs at Peter the Great St. Petersburg Polytechnic University. The results show that the process of foreign premaster's students' adaptation differs in its
\end{abstract}

\section{Аннотация}

Успешная адаптация иностранных студентов к системе высшего образования и жизни в России является актуальной задачей всех программ предвузовской подготовки. Цель данного исследования состоит в определении уровня академической, социальнопсихологической и бытовой адаптации иностранных студентов, обучающихся на программах предмагистерской подготовки, и его сравнении с уровнем адаптации будущих иностранных бакалавров. В ходе эмпирического исследования авторы статьи анализировали результаты опроса 92 иностранных студентов программ

\footnotetext{
${ }^{44}$ Candidate of Philological Sciences, Associate Professor, Director of Center of Russian as a Foreign Language, Higher School of International Educational Programs, Peter the Great St. Petersburg Polytechnic University, St. Petersburg, Russia.

${ }^{45}$ Candidate of Philological Sciences, Associate Professor of Higher School of International Educational Programs, Peter the Great St. Petersburg Polytechnic University, St. Petersburg, Russia.

${ }^{46}$ Candidate of Philological Sciences, Associate Professor of Higher School of International Educational Programs, Peter the Great St. Petersburg Polytechnic University, St. Petersburg, Russia.

${ }^{47}$ Candidate of Philological Sciences, Associate Professor of Higher School of International Educational Programs, Peter the Great St. Petersburg Polytechnic University, St. Petersburg, Russia.

${ }^{48}$ Candidate of Philological Sciences, Associate Professor of Higher School of International Educational Programs, Peter the Great St. Petersburg Polytechnic University, St. Petersburg, Russia.
} 
specificity. In accordance with the competencybased approach in modern education this fact is recommended to be considered when preparing programs of pre-master's training of foreigners for admission to Russian universities.

Key words: adaptation, competency-based approach, foreign students, pre-mater's students, pre-university training.

\section{Introduction}

Creating conditions for the successful adaptation of foreign students to the system of higher education and life in Russia is a relevant objective of pre-university training faculties (departments) as well as an acute objective of Russian as a Foreign Language Teaching Methodology. The issue of adaptation of foreign students proves to be actual as it is frequently discussed by modern professionals including Ignatyeva N. N. (Ignatyeva, 2017), Kogan O. S., Galiullina S. D. (Kogan \& Galiullina, 2019), Pugachev I. A. (Pugachev et al., 2018), Busurina E. V., Kuraleva I. R. (Busurina \& Kuraleva, 2018).

Both future bachelors and foreigners who have already received a bachelor's degree in their home country and who wish to enter master's programs (pre-master's students) in Russia come to university admission training programs.

Pre-master's students differ much from the students of standard pre-university training programs: first, they are older in age, second, they already have experience of participation in the educational process of the university at home (not only school education experience), third, pre-master's students are more independent (both in everyday and social and cultural spheres of life, and in the educational sphere), four, they have high enough level of emotional intelligence that allows them to adapt more quickly to the conditions of new educational environment (Yuanyang, 2018), fifth, representatives of this student body have clearly decided on the choice of major and are well aware of what education outcomes they want to get. Another feature of pre-master's students is that they tend to define quite well their so-called learning style, which refers to "characteristic cognitive, affective, and предвузовской подготовки СанктПетербургского политехнического университета Петра Великого. Исследование выявило специфику процесса адаптации иностранных предмагистров. В соответствии с компетентностным подходом в современном образовании рекомендуется учитывать данную специфику при разработке подготовительных программ для будущих иностранных магистрантов, планирующих поступать в российские вузы.

Ключевые слова: адаптация, компетентностный подход, иностранные студенты, предмагистры, предвузовская подготовка.

psychological behaviors that serve as relatively stable indicators of how learners perceive, interact with, and respond to the learning environment" (Keefe, 1987). This is an important characteristic, since knowledge of the individual learning style has a significant impact on the success of foreign language learning (Feng et al., 2020) and allows developing an individual strategy for stress coping arising when meeting certain educational challenges (Boke et al., 2019).

Awareness of this students' body as special, different from future bachelors and requiring arrangement of special forms of work, the socalled "pre-master's training" is a process that began recently (Vasilyeva, 2016). It complies with the contemporary understanding of conceptual approaches of pedagogy (Lungu \& Silistraru, 2021).

The analysis of the experience of leading foreign universities in implementing pre-master's training of foreigners is presented in the works of experts of Tomsk Polytechnic University (Guzarova et al., 2013). It is they who own the first Russian development and implementation of pre-master's training program.

On the basis of Higher School of International Educational Programs of Peter the Great St. Petersburg Polytechnic University (HS IEP SPbPU) a program of pre-master's training of foreign students is also being developed (Krasnoschekov \& Rud, 2015; Arseniev et al., 2019). The testing of pre-master's training program model built as a part of a competencybased approach (Kazimova et al., 2013; Saliha, 2011) was successful within a few years. All graduates of the program passed entrance exams 


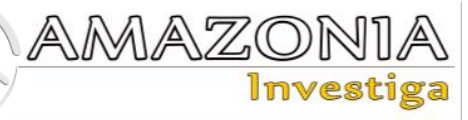

to the master's degree and only $3 \%$ of master's students were expelled, while this share was up to $15-20 \%$ before the program implementation (Krasnoshchekov et al., 2018).

The purpose of this study is to identify the level of academic, social and psychological and personal adaptation of foreign students of the pre-master's training program based on online survey in comparison with the adaptation level of future foreign bachelors. The relevance of this paper is related to the study of a new body of students requiring development of new forms of organizational and methodical work. The novelty of the study is that the survey also involved foreign pre-university students planning to enter the 1 bachelor degree course, which made it possible to compare results obtained from two different categories of foreign students.

\section{Methodology}

The research was conducted in May 2020 in HS IEP SPbPU. The survey conducted in the form of a voluntary anonymous online questionnaire involved 92 respondents, including 57 premaster's students and 35 pre-bachelors students. The choice of the questionnaire method is due to the fact that it allows based on written answers to the proposed questions to identify points of view, trends and problems that occur in the group of respondents (Dolzhenko \& Pozdnyakova, 2015). The content of the questionnaire was developed to determine the level of academic, social and psychological, and everyday life adaptation of these groups of students.

Questionary

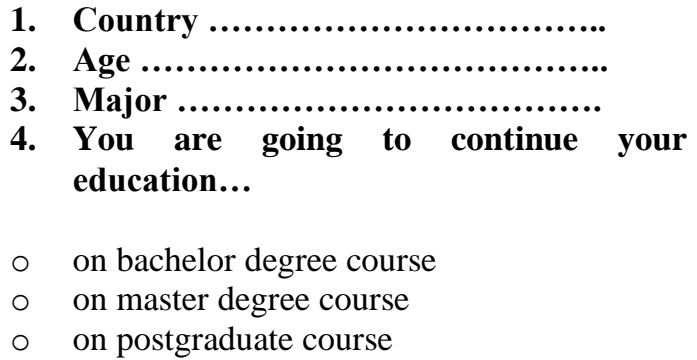

\section{Is it your first visit to Russia?}

A. No, I've already been here

B. Yes, it's my first visit here

○ in Saint-Petersburg

$\circ$ in Moscow

$\circ \quad$ in another place in Russia
6. For how long did you live in Russia before studies in Polytechnic University?

7. Did you study Russian before this visit to Russia?

A. Yes

B. No

8. What is the most difficult thing to learn Russian?

- difficult to pronounce some Russian sounds

o complex gramar

- difficult to read

o difficult to write

- difficult to express my thoughts in Russian (speaking)

$\square \quad$ in Russian language classes

$\square \quad$ in general education classes

$\square$ in the extracurricular sphere (communicating with Russian people)

- difficult to understand Russian people (spoken Russian language)

$\square \quad$ teacher in Russian language classes

$\square \quad$ teacher in general education classes

$\square$ people in the extracurricular sphere (communicating with Russian people)

9. What is your estimation of effectiveness of Russian language classes?

A. High

B. Average

C. Low

10. What should be paid more attention to in Russian language classes?

- Conversation

- language of the specialty

- gramar

- nothing to change, I'm satisfied

o ....................... (your variant of answer)

11. What do you think you need subjects you are currently studying for?

○ for future profesión

- for further studies in Russia

- for Russian language knowledge

○ I don't know what for 
12. What shall be changed in the curriculum content?

- increase the number of Russian classes

- expand the list of general education courses

(which

courses?)

- more time to work independently with Internet resources (websites for learning Russian)

○ more free time for self-tuition

o nothing to change, I'm satisfied

\section{Have you got many friends?}

A. Yes, many

B. No, just few

\section{Have you got Russian friends?}

A. Yes

B. No

15. What are reasons for the lack of Russian friends?

- I don't speak Russian well

- I have no time and opportunity to communicate with Russian students

- I only communicate with foreign students

16. What was the most difficult in the early days in Russia?

- climate

- ignorance of Russian language

○ non-traditional food

○ study

o other.

17. What is the most difficult now - at the end of the first academic year in Russia?

- climate

- ignorance of Russian language

○ non-traditional food

O study

o other...

18. Do you use Russian-language Internet resources?

A. Yes

B. No

19. What Russian-language websites do you visit?
- Educational

- Informational

- Entertainment

O the most frequently visited Russianlanguage website for me (a)

20. Have you joined social networks or messengers where communication is in Russian?

A. Yes

B. No

21. What groups in social networks have you joined? What Russian websites have you registered on?

21. Do you communicate with Russian people on social networks and in messengers?

A. Yes

B. No

Results

Analysis of the responses of pre-master's training programs students revealed the following features of academic adaptation. In general, pre-master's students have not previously studied Russian (86\%), and among future bachelors (pre-bachelors) there are only $45 \%$ of students who have not studied Russian before coming to Russia.

In response to a question aimed at identifying psychology of students' recipience of learning material when studying the foreign language (Qing, 2020) "What is the most difficult thing to learn Russian?" $27 \%$ of pre-master's students note complex grammar and $39 \%$ - difficulty in speaking (Fig. 1).

Pre-bachelors have as expected these figures to be slightly lower (23\% and $31 \%$ respectively) since among them the percentage of those who had previously studied Russian is higher. At the same time, the percentages of fields where it is difficult for respondents to express their thoughts differ in two categories of students.

Pre-bachelors face difficulties of verbal expressing thoughts in Russian language not in classes, but when communicating with Russian people outside the educational process. For comparison, in Russian language classes only $13 \%$ of those for whom expression of thoughts in 


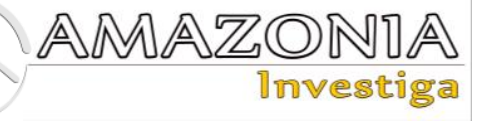

Russian in general is difficult face difficulties in speaking, in general education classes $-38 \%$, in the extracurricular sphere $-49 \%$.

Such a high percentage of communication with Russian people outside of academic activities may probably both indicate a great need of premaster's students to express their thoughts in extracurricular communication, and the need for extracurricular communication in general. The results of pre-bachelors' survey showed that the most difficult for them is communication in general education classes (57\%), less difficult communication in the extracurricular sphere. The indicator reflecting the attitude of pre-bachelors to the difficulties of speaking during Russian classes roughly coincided with the values of premaster's students (10\%).

These results reveal the other side: the apparent ease of expressing thoughts in Russian language classes for pre-master's students gives cause for concern. This may indicate that at Russian language classes students simply do not have to express their thoughts, as the educational process does not set (or does not set in sufficient extent) educational and methodical tasks aimed at producing student's own original statement (verbal and cogitative tasks). Perhaps it is worth thinking about giving an emphasis on productive speech activities in pre-master's Russian language training programs as these types of speech activities allow showing cognitive independence typical for pre-master's students.
$20 \%$ of surveyed pre-master's students say that the greatest difficulty in learning Russian is a poor understanding of spoken Russian language. Moreover, the speech of the Russian language teacher is clear to almost everyone (only 6\% noted difficulties in understanding what the teacher says in the classes), the speech of subjectteachers - to the majority ( $25 \%$ face difficulties to understand), and understanding of Russian people in out-of-class communication is difficult for $69 \%$ of pre-master's respondents (the last value is almost half less for pre-bachelors - only $34 \%$ ). These are expected results as related to the proportion of distribution of difficulties in Russian speech understanding, but again the very low percentage of difficulty of educational communication in Russian language classes makes one think about increasing complexity of speech communication models within the educational process, since as practice shows foreign students have serious difficulties in listening to lectures in the conditions of study at the master's stage (Busurina \& Kuraleva, 2017; Mehar Singh, 2019). The high percentage of difficulty in understanding what Russian people say outside the educational process indicates a high need of pre-master's students for communication.

Phonetics ("difficult to pronounce some Russian sounds") and writing ("difficult to write") cause minor difficulties for both bodies of respondents. Pre-master's students facing difficulties in reading are almost 2 times less often than prebachelors ( $6 \%$ and $15 \%$ respectively).

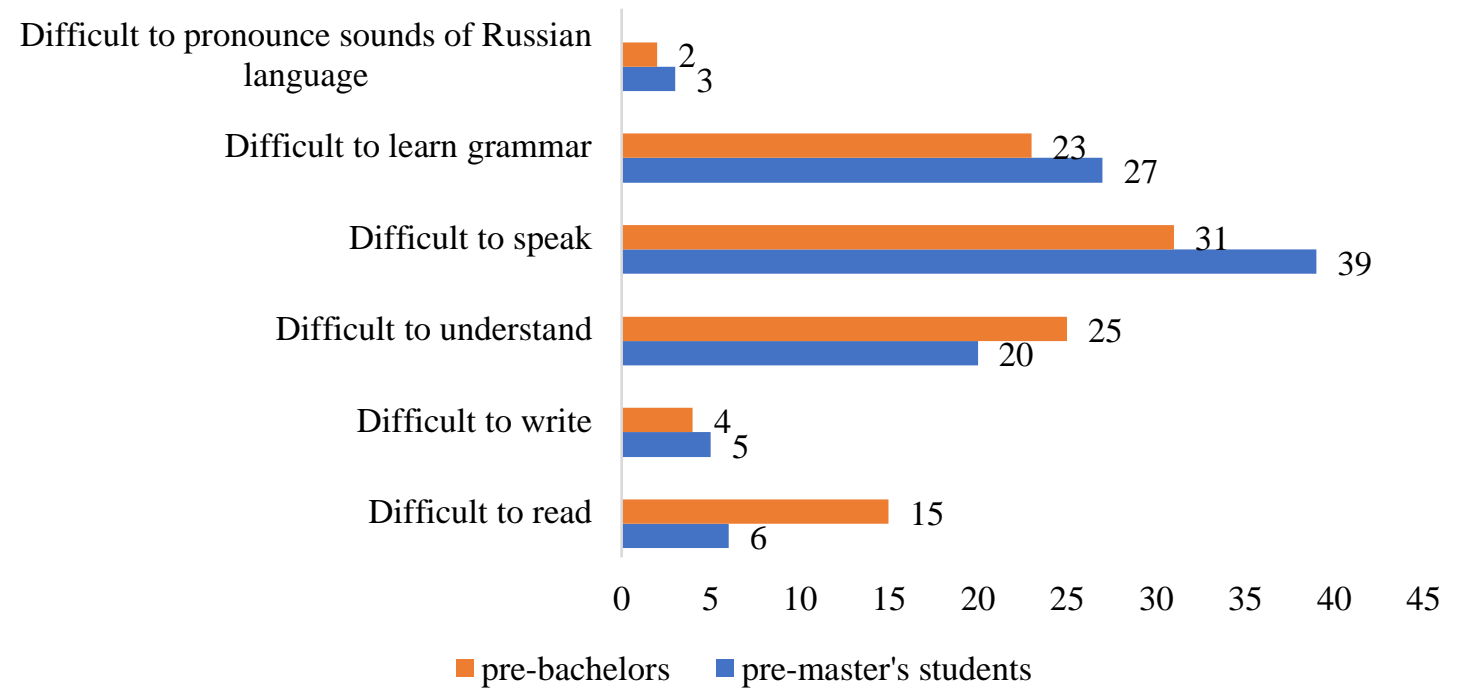

Fig. 1. Distribution of responses to the question of the degree of foreign students' recipience of learning material when learning Russian (own authorship) 
Interesting results showed responses to the question about the effectiveness of Russian language classes. As it is shown in Fig. 2, the indicators among pre-master's students and prebachelors are significantly different: $74 \%$ of prebachelors and only $41 \%$ of pre-master's students note high efficiency of classes, average efficiency $-23 \%$ of pre-bachelors and $48 \%$ of pre-master's students, low $-3 \%$ of pre-bachelors and $11 \%$ of pre-master's students. That is, premaster's students assess effectiveness of teaching Russian language significantly lower than pre- bachelors, while the groups of pre-master's training are taught by the most experienced teachers, which allows for excluding the impact of assessing the professional level of teaching on the questionnaire answers. Probably, premaster's students are more demanding to the thematic material of classes: they expect that the material will correspond as much as possible to their future specialty and help them in communicating with teachers in the field of specialty and future research supervisor.

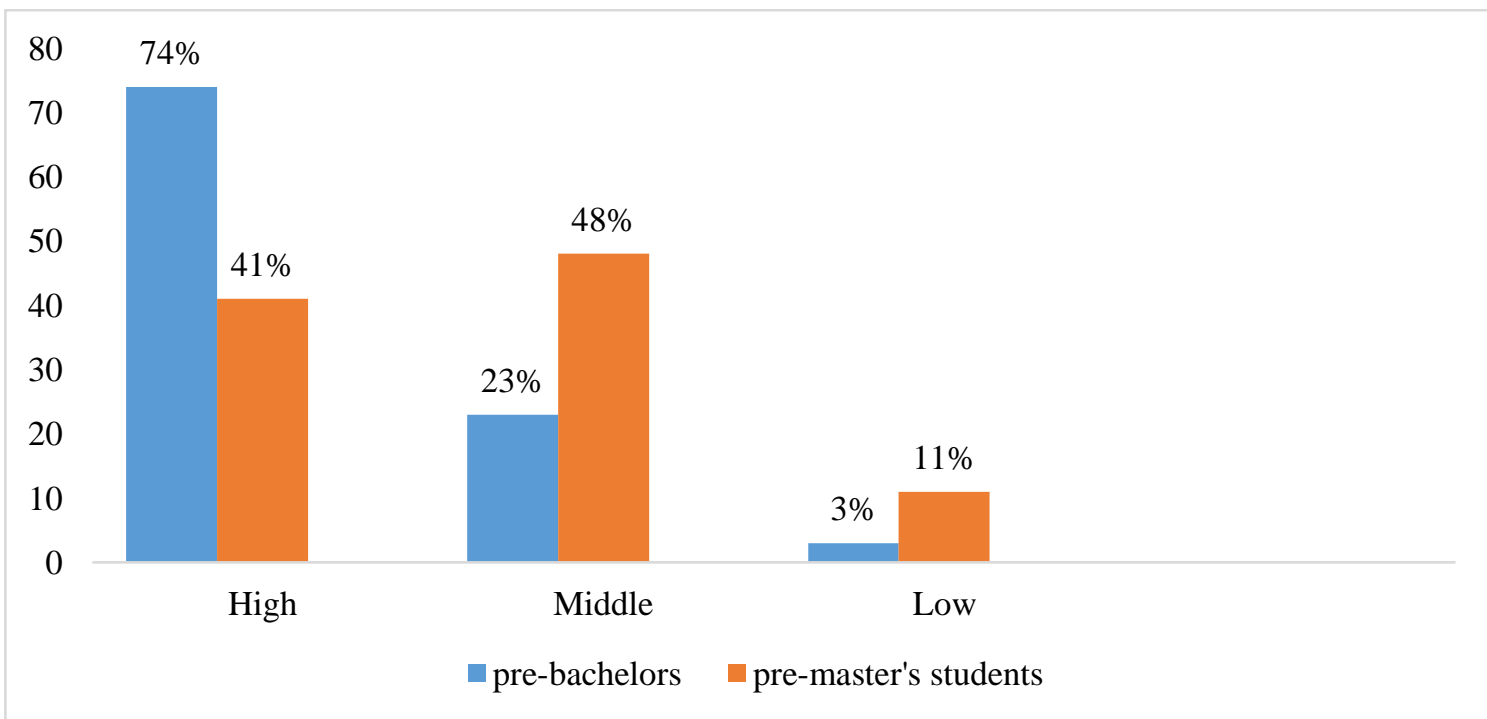

Fig. 2. Distribution of responses to the question about the effectiveness of Russian language classes (own authorship)

The question of the questionnaire "What should be paid more attention to in Russian language classes?" also revealed wishes of pre-master's students in relation to improving of education effectiveness. Results presented in Fig. 3, show that $48 \%$ of respondents noted "conversation" (the aspect of speaking), while among prebachelors this value is much less $-27 \%$. Also, pre-master's students want to devote more time to the language of the specialty in Russian language classes $-36 \%$ of pre-master's students and only $21 \%$ of pre-bachelors checked this item of the questionnaire. Increased attention to grammar is higher in the pre-bachelors group $(52 \%)$.

Thus, we again see a great need of pre-master's students in communication and their desire to pay more attention to learning language of the specialty is naturally traced. 


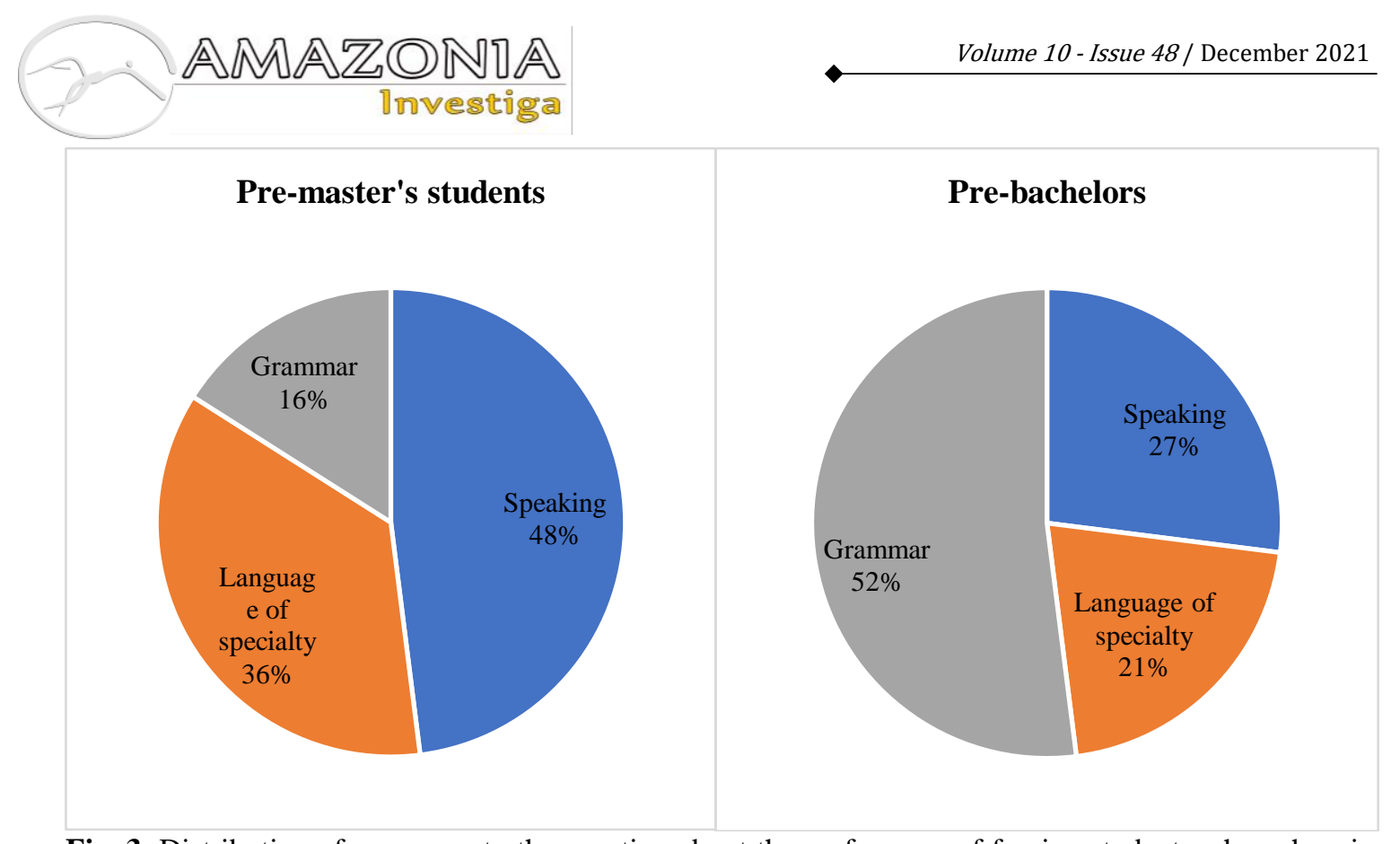

Fig. 3. Distribution of responses to the question about the preferences of foreign students when choosing aspects of learning Russian (own authorship)

Pre-master's students showed more critical responses to the question "What shall be changed in the curriculum content?" as $45 \%$ of prebachelors are satisfied with the content and do not want to change anything, and the premaster's percentage of satisfied with the educational program content is only $20 \%$. These responses revealed a request for more time to work independently with Internet resources, as well as a request for more free time. Compared to pre-bachelors, the figures are as follows (Fig. 4): $46 \%$ of pre-master's students and $21 \%$ of pre-bachelors want to increase their time for independent work. $19 \%$ of pre-master's students would like to expand the list of general education courses and pre-bachelors show little interest in increasing their number. The survey shows the existing request of pre-master's students to increase independent work, work with Internet resources, and demonstrate their academic interest.

As related to the desire to increase the number of Russian classes pre-bachelors showed much greater interest (77\%) compared to pre-master's students $(27 \%)$.

However, in respect of the mastery of other subjects in Russian language the survey showed mixed results. On the one hand, pre-master's students show interest in studying general education subjects, want to increase the number of hours designated for them, but on the other hand, they show a lower percentage of responses (compared to pre-bachelors) indicating that these subjects are necessary for the future profession. And what's more, some pre-master's students don't know why they need to study subjects that are part of the pre-master's program: when answering the question "What do you think you need subjects you are currently studying for?" $18 \%$ of pre-master's students chose the answer option 'I don't know what for' (none of surveyed pre-bachelors checked this item of the questionnaire).

Perhaps such results show that pre-master's students are dissatisfied with the material they master in general education classes or with the set of subjects. It is worth considering the initial subject training of pre-master's students: they have already studied general subjects in the bachelor's degree course and are probably tuned to a narrower specialization. Increasing the correlation between the content of pre-university training and master's degree education is possible with the use of innovative modular learning technology, which allows flexibility in the content of learning, thereby significantly increasing the effectiveness of forming communication competence of foreign students in the educational and scientific field of communication (Gorbenko et al., 2020). 


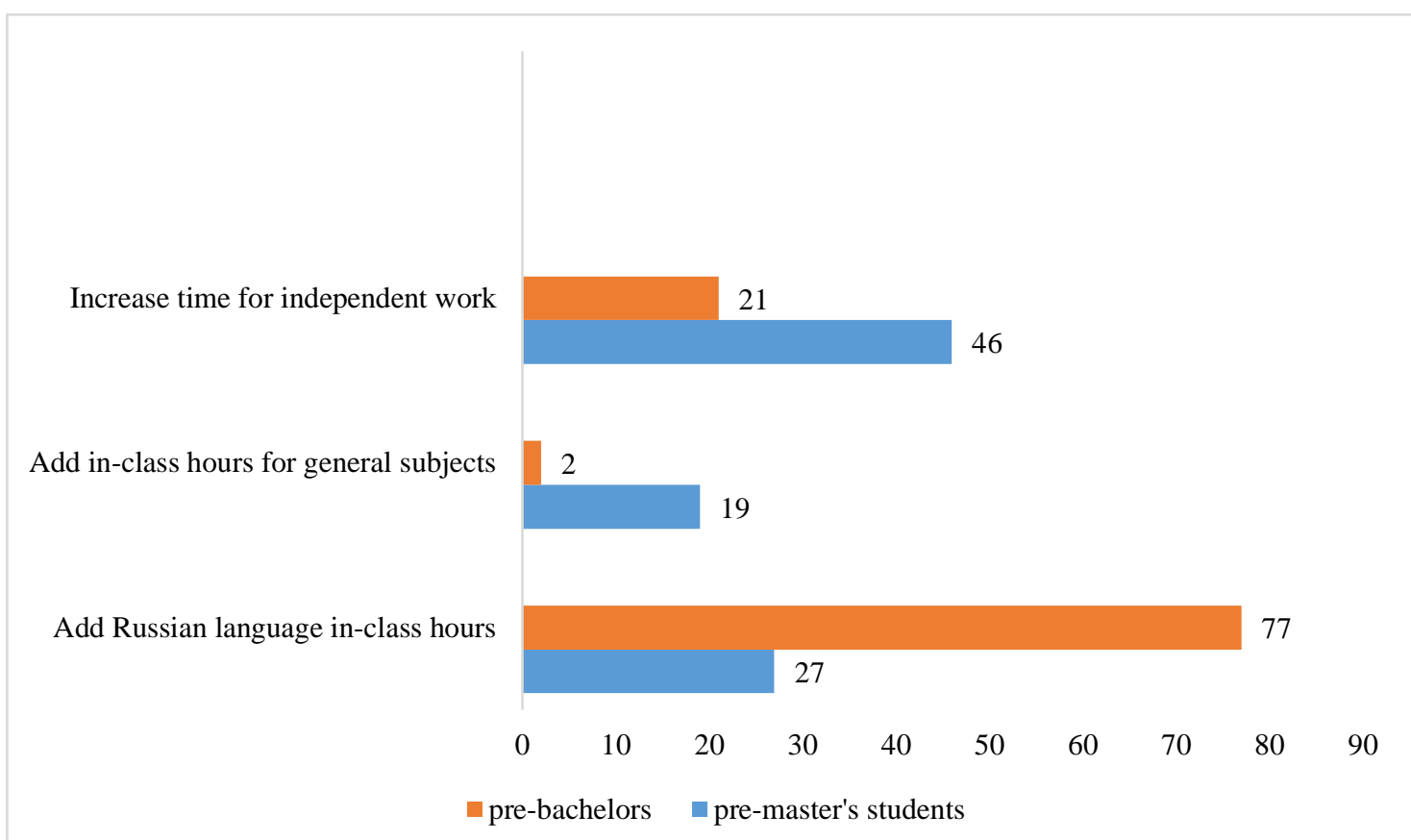

Fig. 4. Distribution of responses to the question about changing the content of the educational program (own authorship)

In addition to the level of academic adaptation described above, the questionnaire items were also aimed at revealing the degree of social and everyday life adaptation of pre-university training program foreign students. Results of the survey are given in Table 1. Respondents' answers to questions about the difficulties of different periods of adaptation ("what was the most difficult in the early days in Russia" and "what is the most difficult now", i.e. at the end of the academic year) make a similar picture for premaster's students and pre-bachelors: during the first days the most difficult was ignorance of language for $73 \%$ of pre-master's students and $39 \%$ of pre-bachelors (given that among the prebachelors there are more people who studied Russian before coming to Russia), the second study (for $14 \%$ of pre-master's students) and nontraditional food (for $31 \%$ of pre-bachelors).

Table 1.

The degree of social and everyday life adaptation of pre-university training program foreign students

\begin{tabular}{lcc}
\hline Question & $\begin{array}{l}\text { Results of pre-master's } \\
\text { students' responses }\end{array}$ & $\begin{array}{l}\text { Results of pre-bachelors' } \\
\text { responses }\end{array}$ \\
\hline 1. What was the most difficult in the early days in Russia? & \\
ignorance of Russian language & $73 \%$ & $39 \%$ \\
climate & $5 \%$ & $21 \%$ \\
non-traditional food & $8 \%$ & $31 \%$ \\
study & $14 \%$ & $9 \%$ \\
2. What is the most difficult at the end of the first academic year in Russia? \\
ignorance of Russian language & $23 \%$ & $15 \%$ \\
climate & $21 \%$ & $19 \%$ \\
non-traditional food & $20 \%$ & $26 \%$ \\
study & $36 \%$ & $40 \%$ \\
3. Do you have Russian friends? & & \\
yes & $50 \%$ & $36 \%$ \\
no & $50 \%$ & $64 \%$ \\
4. What are reasons for the lack of Russian friends? & $59 \%$ \\
I don't speak Russian well & $55 \%$ & \\
\hline
\end{tabular}




\begin{tabular}{lcc}
\hline $\begin{array}{l}\text { I have no time and opportunity to } \\
\text { communicate with Russian students }\end{array}$ & $27 \%$ & $24 \%$ \\
$\begin{array}{l}\text { I only communicate with foreign } \\
\text { students }\end{array}$ & $18 \%$ & $17 \%$
\end{tabular}

\section{Do you use Russian-language Internet resources?}

$\begin{array}{lll}\text { yes } & 100 \% & 98 \% \\ \text { no } & 0 \% & 2 \%\end{array}$

6. What Russian-language websites do you visit?

$\begin{array}{lll}\text { educational } & 41 \% & 35 \% \\ \text { information } & 37 \% & 31 \% \\ \text { entertainment } & 22 \% & 34 \%\end{array}$

\section{Do you communicate with Russian people on social networks and in messengers?}

\begin{tabular}{lll} 
yes & $31 \%$ & $37 \%$ \\
no & $69 \%$ & $63 \%$ \\
\hline
\end{tabular}

(own authorship)

At the end of the academic year, these factors remain the main difficulties, but the percentage of responses varies: language ignorance remains difficult for $23 \%$ of pre-master's students and $15 \%$ of pre-bachelors, and learning difficulties are increasing - $36 \%$ of pre-master's students and $40 \%$ of pre-bachelors note that they find it difficult to study at the end of the academic year.

The survey data show that a greater number of pre-master's students has Russian friends $(50 \%$ of pre-master's students and $36 \%$ of prebachelors). Reasons why the rest of respondents do not have Russian friends are indicated similar for both pre-master's students and pre-bachelors (including in percentage): more than half of respondents indicate poor knowledge of Russian language, a third of respondents - lack of time and opportunity, $18 \% / 17 \%$ of respondents chose answer option "I communicate only with foreign students".

As the results of the survey showed, almost all respondents use Russian- language Internet resources. Pre-master's students use more Internet resources for learning, and pre-bachelors show a slightly higher percentage of entertainment Internet resources use, but in general the differences are insignificant. Yandex service is the most popular among all respondents.

$31 \%$ of pre-master's students and $37 \%$ of prebachelors communicate with Russians on social networks or messengers. The most popular resources are VK, FB, WhatsApp.

\section{Discussion}

Based on the data obtained as a result of preuniversity training program students' questionnaire it is possible to analyze the special features of pre-master's students and their educational requests: pre-master's students show a higher criticality in respect of the curriculum; pre-master's students are more focused on learning, more conscious in their approach to studying; pre-master's students show an increased interest in communication in Russian language outside the classroom; pre-master's students want to increase the number of hours in the program designated for Russian language classes and other disciplines, but at the same time demonstrate the need to increase the share of independent work and want to get more free time; pre-master's students need to get more specialized knowledge in terms of the chosen course; pre-master's students need more fieldspecific programs when learning the language of the specialty, composed considering the distinction of specialties within the same educational field.

The results can be explained by the fact that most of pre-university training programs students are represented by students from the People's Republic of China, who have limited communication interaction with people of the country where they have come, which is a factor in slowing down the development of their intercultural competence. Such results fully comply with the earlier relevant study (Lai \& Lu, 2020). The results may be related to the fear of Chinese students making a mistake and losing face (Kupchina \& Ragulskaya, 2018), while students from Turkey, for example, are open to any negative experience of making possible mistakes, which has a positive effect on their adaptation to the new educational environment (Pidbutska \& Knysh, 2020). A study conducted at the Peoples' Friendship University of Russia showed that students from Afghanistan and Africa needed additional psychological support 
in the course of cultural adaptation (Novoselova et al., 2020).

One of solutions to the problem of increasing the degree of successful intercultural communication between foreign students may be their study of intercultural communication course at the stage before their arrival at the country where they will receive their higher education (Fang et al., 2020) or support through online learning (Litvinova et al., 2021). During study, strategies such as assistance in social and cultural issues, psychological and pedagogical support, effective interpersonal communication of students (Bilotserkovets et al., 2020) and communicative intervention method based on communication scenarios (Thomas \& Waugh, 2020) can be applied to improve intercultural adaptation of foreign students.

The importance and relevance of online communication which is revealed in this study is also noted in the research aimed at studying psychological aspects of international students' adaptation to the new educational environment (Kostyushina et al., 2020).

\section{Conclusions}

The results of the study show the specificity of adaptation process of foreign students of premaster's training program which is determined by the students' cognitive, age, psychological, motivational, and communicative peculiarities.

These findings and results of the study are recommended to consider in accordance with the competency-based approach in modern education when preparing programs of premaster's training of foreigners for admission to Russian universities. One of the possible prospects for the study development is research of life, social and academic experience of foreign students based on analysis of the interview materials.

\section{Bibliographic references}

Arseniev, D. G., Gorbenko, V. D., Krasnoshchekov, V. V., \& Rud, V. Yu. (2019) Forming of professional culture of foreign students of pre-master training program. The European Proceedings of Social \& Behavioural Sciences EpSBS, pp. 794-805. DOI: https://doi.org/10.15405/epsbs.2019.12.84 URL:

https://www.elibrary.ru/item.asp?id=424102 39
Bilotserkovets, M., Fomenko, T., Gubina, O., Berestok, O., Shcherbyna, Y., \& Krekoten, O. (2020) Multifaceted Problems of Intercultural Adaptation: A Case Study of Chinese Students in Ukraine. BRAIN. Broad Research in Artificial Intelligence and Neuroscience, 11(1), 178-188. DOI: https://doi.org/10.18662/brain/11.1/22

Blynova, O., Popovych, I., Semenova, N., Kashyrina, Y., Ursulenko, O., \& Kononenko, O. (2020). Personality Factors of Choosing Adaptation Strategies in a Different Cultural Environment by Labor Migrants from Ukraine. Amazonia Investiga, 9(32), 45-54. https://doi.org/10.34069/AI/2020.32.08.5

Boke, B. N., Mills, D. J., Mettler, J., \& Heath, N. L. (2019) Stress and Coping Patterns of University Students. Journal of college student development, 60, No. 1, 85-103.

DOI: https://doi.org/10.1353/csd.2019.0005

Busurina, E. V. \& Kuraleva, I. R. (2017) The professionally oriented listening in foundation program for international students. Pre-university stage of education in Russia and the world: language, adaptation, society, specialty, 1, 107-110. (in Russian). URL:

https://www.elibrary.ru/item.asp?id=325658 61

Busurina, E. V. \& Kuraleva, I. R. (2018) Early adaptation stage for foreign students: objectives and approaches. St. Petersburg State Polytechnical University Journal. Humanities and Social Sciences, 9(3), 107-115. (in Russian). DOI: https://doi.org/10.18721/JHSS.9311 URL: https://www.elibrary.ru/item.asp?id=370262 87

Dolzhenko, Y. \& Pozdnyakova, A. (2015) Online questionnaire survey as a modern and effective way of research. Transport business of Russia, 1, 109-110. (in Russian). URL: https://www.elibrary.ru/item.asp?id=236604 62

Fang, F., Zhang, S., \& Elyas, T. (2020) Role of prior intercultural learning in Chinese University students' cross-cultural adaptation. Pertanika Journal of Social Sciences and Humanities, 28(3), 1599-1619. URL:

https://www.researchgate.net/publication/34 4378686_Role_of_Prior_Intercultural_Learn ing_in_Chinese_University_Students'_Cross -cultural_Adaptation

Feng, Y., Iriarte, F., \& Valencia, J. (2020) Relationship Between Learning Styles, Learning Strategies and Academic 


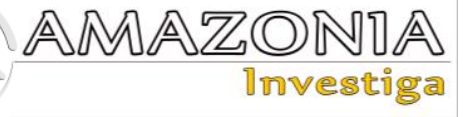

Performance of Chinese Students Who Learn Spanish as a Foreign Language. Asia-Pacific Education Researcher, 29, 431-440. DOI: https://doi.org/10.1007/s40299-019-00496-8

Gorbenko, V. D., Dominova, T. N., Ilina, N. O., \& Mityakova, M. V. (2020) The use of modular technology in the formation of the communicative competence of foreign students of the humanitarian profile in the educational and scientific sphere of communication at the stage of pre-university training. Perspectives of Science and Education, 47(5), 160-169. DOI: https://doi.org/10.32744/pse.2020.5.11 URL: https://www.elibrary.ru/item.asp?id= 44130097

Guzarova, N. I., Kashkan, G. V., \& Shakhova, N. B. (2013) Analysis of the experience of foreign and Russian universities in the implementation of premaster training for foreign citizens. Level-up training of specialists: state and international standards for engineering education. Tomsk: National Research Tomsk Polytechnic University, pp. 303 - 306. (in Russian). URL: https://elibrary.ru/item.asp?id=20896484

Ignatyeva, N. N. (2017) Assessment of Adaptation Level of Foreign Students in Universities of Russia and Europe on the Example of Nizhny Novgorod State Engineering and Economic University. KANT, 4 (25), 50-54. (in Rusian). URL: https://www.elibrary.ru/item.asp?id=307781 17

Kazimova, D.A., Kipshakov, S.A., \& Sharzadin, A.M. (2013) Competency building approach to the training of itspecialists in the information-educational environment. International Journal of Experimental Education, 7, 27-31 (in Russian). URL: https://elibrary.ru/item.asp?id=20218551

Keefe, J. W. (1987) Learning style theory and practice. Reston, VA: National Association of secondary School Principals, p. 4.

Kogan, O. S. \& Galiullina, S. D. (2019) Sociopsychological aspects of the adaptation of foreign students in training in USPTU. Bulletin USPTU. Science, Education, Economy. Series Economy, 1 (27), 95-99. (in Russian).

URL: https://www.elibrary.ru/item.asp?id=373819 01

Kostyushina, Y.I., Stroiteleva, N.N., Lobuteva, A.V., \& Tikhonova, Y.A. (2020) Psychological and cultural adaptation of foreign students to the new educational environment. Opcion, 36, issue Special Edition, 26, 594-612.
Krasnoschekov, V. V. \& Rud, V. Yu. (2015) Experience in the organization and training of foreign citizens in accordance with the program of pre-master at Peter the Great St. Petersburg Polytechnic University. Bulletin Tula State University. Series Modern educational technologies in teaching natural sciences, 14, 26-29. (in Russian). URL: https://www.elibrary.ru/item.asp?id=248955 36

Krasnoshchekov, V. V., Rud, V. Yu., \& Davydov, V. V (2018) Models of training of foreign students of pre-master study programs in engineering. Modern scientific technologies, 12, 214-219. (in Russian). URL:

https://www.elibrary.ru/item.asp?id=368108 93

Kupchina, M. N. \& Ragulskaya, G. V. (2018) Academic adaptation problems of Chinese learners in the system of pre-university training (as an example of premagistrates of economic specialties in the Institute of Russian Language and Culture of Lomonosov Moscow State University). Teaching natural sciences and humanities in Russian in a foreign language audience. Moscow State University named after M.V. Lomonosov, Moscow, Russia, pp. 87-92. (in Russian). URL: https://www.elibrary.ru/item.asp?id=372203 65

Lai, M. \& Lu, G. (2020) Adapting to a new learning environment: Mainland Chinese students studying in master's degree programmes in Hong Kong'. London Review of Education, 18(2), 250-264. DOI: https://doi.org/10.14324/LRE.18.2.08

Litvinova, T., Andriutsa, N., \& Movchun, V. (2021) Developing Students' Intercultural Communicative Competence through Online Learning. International Journal of Emerging Technologies in Learning (iJET), 16(08), 162-172. URL: https://onlinejournals.org/index.php/ijet/article/view/18947

Lungu, V. \& Silistraru, N. (2021) Conceptual Approaches of Prospective Pedagogy. International Journal of Emerging Technologies in Learning (iJET), 16(18), 69-84. URL: https://onlinejournals.org/index.php/ijet/article/view/25169

Mehar Singh, M. K. (2019) Lecturers' views: Academic English language-related challenges among EFL international master students. Journal of Applied Research in Higher Education, 11(2), 295-309. DOI: 
https://doi.org/10.1108/JARHE-07-20180117

Novoselova, N., Bondareva, V., Semanina, A., Chistyakov, A., \& Zetkina, A. (2020) Adaptation of foreign pre-graduate students in the university multicultural educational environment. Utopia y Praxis Latinoamericana, 25, issue Extra 5, 196-205. DOI: https://doi.org/10.5281/zenodo.3984232

Pidbutska, N. \& Knysh, A. (2020) ErrorOriented Motivation of Turkish Students During their Adaptation to a Foreign University. New Educational Review, 60, 49-60. URL: https://tner.polsl.pl/e60/a4.pdf

Pugachev, I. A., Budiltseva, M. B., \& Varlamova, I. Yu. (2018) Adaptation of foreign students to the conditions of life and education in Russia: a complex approach. RUDN Journal of Language Education and Translingual Practices, 15(2), 225-235. (in Russian).

DOI: https://doi.org/10.22363/2312-8011-201815-2-225-235 URL: https://www.elibrary.ru/item.asp?id=349776 71

Qing, N. (2020) Psychological mechanism and law of audience acceptance in teaching of Chinese as a foreign language. Revista
Argentina de clínica psicológica, XXIX, no. $1, \quad 1210-1215 . \quad$ DOI: https://doi.org/10.24205/03276716.2020.173

Saliha, C. (2011) The competency-based approach in Higher Education. Revue Des Sciences Humaines, 22, 21-31.

Thomas, R. S. \& Waugh, C. E. (2020) Effects of script-based communicative intervention on psychological and cultural adaptation in students abroad in second language contexts. Intercultural Education, 31(2), 244-259. DOI: https://doi.org/10.1080/14675986.2019.1702 295

Vasilyeva, T. V. (2016) «Introduction to a postgraduate program» special course: learning content, aims, addressee, learning materials. International education and intercultural communication: problems, searches, solutions, Tomsk, pp. 21-26. (in Russian). URL:

https://www.elibrary.ru/item.asp?id=284293 17

Yuanyang, W. (2018) Emotional intelligence and socio-psychological adaptation of foreign students in Russian universities (using the example of the Chinese students). Problems of modern education, 2, 65-71. URL: https://www.elibrary.ru/item.asp?id=328783 31 